Arch. Tierz., Dummerstorf 45 (2002) 2, 205-209

Department of Animal Science, Obafemi Awolowo University, Ile Ife, Nigeria

OLUYINKA A. OLUKOSI, OLAJUMOKE C. DANIYAN and OPES MATANMI

\title{
Effects of feeder space allowance on agonistic behaviour and growth performance of broilers (short communication)
}

\begin{abstract}
Summary
One hundred and thirty-two 4-weeks old unsexed Anak-2000 broiler strain were used to study the effect of feeder space allowance on agonistic behaviour and growth performance of broilers from weeks $4-8$. The feeder space allowance were $2.4 \mathrm{~cm} / \mathrm{bird}, 3.0 \mathrm{~cm} /$ bird and $3.6 \mathrm{~cm} /$ bird in groups I, II and III. The agonistic behaviour observed included head pecks, steps, pushes, threats and chase during feeding and "non-feeding” periods.

There was a decrease in total agonistic behaviour as feeder space per bird increased from $2.4 \mathrm{~cm} / \mathrm{bird}$ to 3.6 $\mathrm{cm} /$ bird, both during feeding and non-feeding periods. There was a significant effect $(\mathrm{p} \leq 0.05)$ of feeder space allowance on mean agonistic acts/bird/hour during feeding period being highest in G1 (7.8 acts/bird/hour), and lowest in G3 (4.5 acts/bird/hour). There was no significant effect ( $p>0.05$ ) of feeder space allowance on mean agonistic acts/bird/hour during non-feeding period. In G1 and G2, there was a significant effect $(\mathrm{p} \leq 0.05)$ of period of observation on mean agonistic acts/bird/hour being highest in the feeding period and lowest in the nonfeeding periods. In G3, there was no significant effect ( $p>0.05$ ) of period of day on mean agonistic acts/bird/hour and no significant effect of feeder space allowance on the growth performance parameters measured at $\mathrm{p}>0.05$
\end{abstract}

Key Words: broiler, feeder space, agonistic behaviour, growth performance, Nigeria

\section{Zusammenfassung}

Titel der Arbeit: Einfluss der Fressplatzlänge auf das agonistische Verhalten und das Wachstum von Broilern (Kurzmitteilung)

An 132 Anak-2000 Broilern wurde der Einfluss der Fressplatzlänge auf agonistische Verhaltensmerkmale sowie Wachstum und Futtereffizienz zwischen der 4. und 8. Lebenswoche untersucht. Die Fressplatzlänge variierte von 2,4 über 3,0 bis 3,6 cm je Tier. Signifikante Unterschiede in der Anzahl der Akte je Tier und Stunde konnten zwischen Versuchsgruppen während der Futterzeiten beobachtet werden, wobei die Anzahl der Akte mit zunehmender Fressplatzlänge abnahm. In der Verteilung der unterschiedlichen Akte wie Kopfpicken, Drohgebärden, Tritten, Stössen oder Vertreibungen ergaben sich keine Beziehungen zur Fressplatzlänge. Sowohl bezüglich der Gewichtsentwicklung als auch der Futtereffizienz ergab sich kein signifikanter Einfluss unterschiedlicher Fressplatzlänge, so dass 2,4 cm je Tier als ausreichend angesehen wird.

Schlüsselwörter: Broiler, Fressplatzlänge, agonistisches Verhalten, Wachstum, Nigerien

\section{Introduction}

Increase in demand for poultry protein and advancement in technology have led to selection of birds to meet these rising needs and birds are forced to fit into designs that are largely unnatural to them. It has been argued that in domestication of economically important species, economics rather than welfare of the animal is the major consideration (SIEGEL, 1993).

However, an effective management system must take poultry behaviour into consideration, since behaviour is an indicator of welfare (OLUYEMI and ROBERTS, 1988). In poultry management, stocking density is an important consideration because 
of its effect on growth performance of birds. Feeder space allowance is, understandably, a function of stocking density. The effects of feeder space allowance on agonistic behaviour and growth performance of broilers are documented (ANDERSON and ADAMS, 1992; CUNNIGHAM, 1981; OUART and ADAMS, 1982). OLUYEMI and ROBERTS (1988) specified that a feeder space allowance of $2.4 \mathrm{~cm} /$ bird will be sufficient for broilers from $4-8$ weeks of age.

The effects of feeder space allowance on agonistic interaction in birds raised in the tropical environment are lacking. Indeed, there is a general paucity of information on the application of poultry behaviour to poultry management in the tropics. This study was therefore undertaken to determine the effects of feeder space allowance on agonistic behaviour and growth performance of broilers.

\section{Materials and methods}

One hundred and thirty-two day-old unsexed ANAK-2000 broiler strain procured from a commercial hatchery were used for this study. They were randomly allotted to three different groups at day-old, care being taken to minimize weight differences between the groups. Each group had 2 replicates of 22 birds per replicate. There was no observation of behaviour until the end of the fourth week. In each replicate, the flight feathers on one wing were cut to prevent birds from flying over to the other replicate. Water was supplied ad libitum daily in plastic fountain drinkers. Feed was supplied daily at approximately 0630 hours (GMT).

In group I (G1), a feeding space allowance of $2.4 \mathrm{~cm} /$ bird was used. In group II (G2), a feeding space allowance of $3.0 \mathrm{~cm} /$ bird was used, while a feeding space allowance of $3.6 \mathrm{~cm} /$ bird was used in group III (G3).

\section{Behaviour Observation}

At every 3-day interval, water was first supplied to all the groups at the same time, but feed was supplied to the group to be observed in turns. Immediately, after the feed is supplied, the observer sat in front of each pen and observed each replicate for 10 minutes while the birds were feeding. One hour was spent observing the three groups.

In the afternoon of the days of behaviour observation (1400 hours GMT) the birds were also observed for all occurrences of agonistic interaction during these "nonfeeding" periods. The door was closed when the observer entered, the birds were given a five-minute adjustment period to adjust to the presence of the observer. Two replicates of each group were observed simultaneously for 15 minutes.

All occurrences of head pecks, steps, pushes, threats, and chases were recorded during the feeding and "non-feeding" periods. The behaviours were defined according to STONE et al. (1984) and O’KEEFE et al. (1988).

\section{Growth Performance Measurements}

Birds were weighed weekly to note the weekly body weight gain which was transposed to daily body weight gain. Daily feed consumption was measured. The values were used to compute the Feed Conversion Efficiency (FCE).

Statistical Analysis

All the data on the effect of feeder space allowance and the growth performance parameters measured were analyzed using analysis of variance as outlined by 
SNEDECOR and COCHRAN (1967) while the effect of the time of day of agonistic behaviour was compared using t-test. Means that were statistically different were separated by Duncan's multiple range test, DUNCAN (1955). Significance was determined at $\mathrm{p} \leq 0.05$.

\section{Results}

Table I shows the totals and means of agonistic interaction among birds during the feeding and "non-feeding" periods. As feeder space increased by $0.6 \mathrm{~cm} / \mathrm{bird}$, there was a decrease in the total and mean agonistic acts/bird/hour during the 6-week observation period. The totals during the feeding period were 431, 331 and 249 in groups 1, 2 and 3 respectively, and 77, 66 and 61 in groups I, II, and III during the non-feeding” periods. There was a significant effect of feeder space allowance on the mean agonistic acts/bird/hour among the groups being 7.8, 7.0 and 4.5 acts/bird/hour in groups I, II and III respectively. The total and mean agonistic acts/bird/hour during "non-feeding" periods were much lower than during the feeding periods. The mean agonistic acts/bird/hour during "non-feeding” times were 5.9, 5.1 and 4.7 in groups I, II and III respectively. There was statistical significant effect of feeder space allowance on the agonistic acts/bird/hour, except in group III where there was no significant difference between the agonistic acts committed between the feeding and "non feeding” periods.

Table I

Total and Mean of Agonistic acts/bird/hour during Feeding (F) and "Non Feeding” (NF) periods

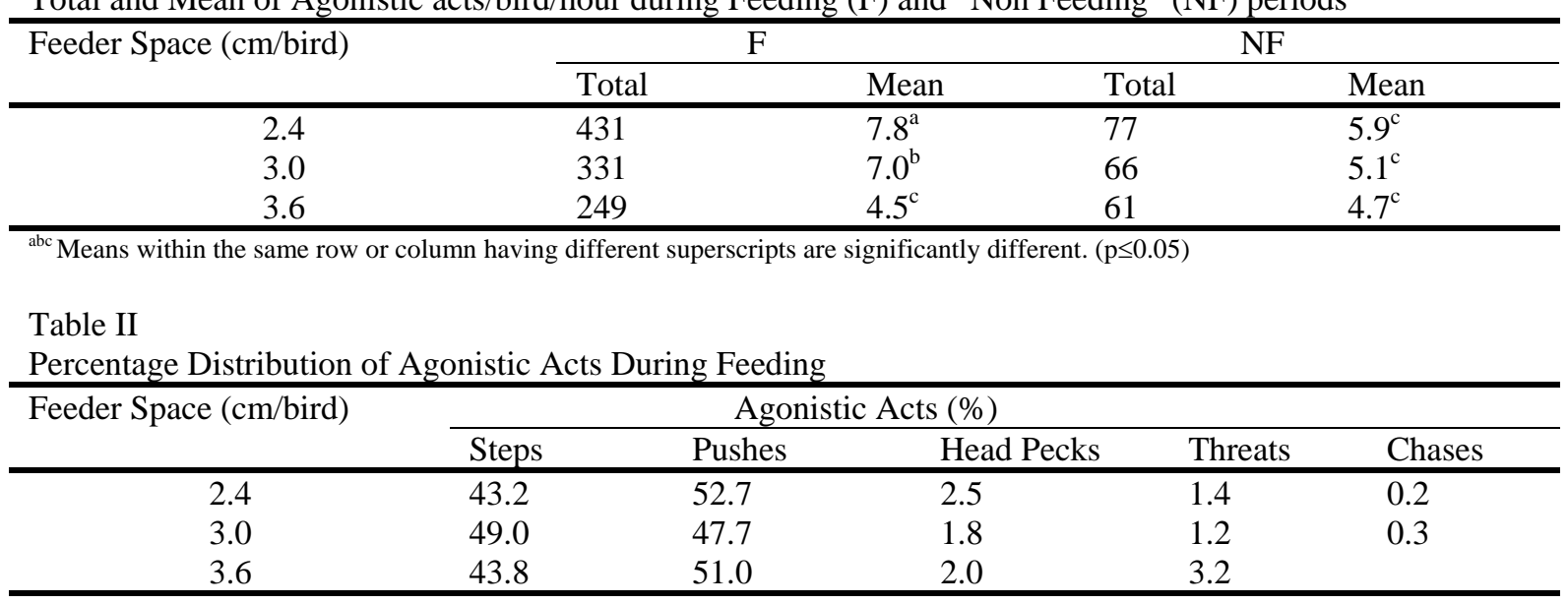

Table III

Performance of broilers up to 10 weeks as affected by feeder space allowance

\begin{tabular}{cccc}
\hline Feeder Space (cm/bird) & $\begin{array}{l}\text { Feed Consumed } \\
\text { (g/bird/day) }\end{array}$ & $\begin{array}{l}\text { Body Weight Gain } \\
\text { (g/bird/day) }\end{array}$ & Feed Efficiency \\
\hline 2.4 & 112.5 & 36.8 & 3.1 \\
3.0 & 115.1 & 37.9 & 3.1 \\
3.6 & 114.0 & 38.5 & 3.1 \\
Mean & 113.9 & 37.7 & 3.07 \\
SEM & 6.6 & 4.2 & 0.87 \\
\hline
\end{tabular}

There was no significant effect of feeder space allowance on any of the growth performance parameter (p>0.05).

Table II shows the different types of agonistic acts performed by birds and their percentage distribution during feeding periods. Of all the agonistic acts observed steps and pushes make up more than $90 \%$ of the total acts committed in all the groups. Chases were very rarely observed, and, indeed was not observed at all in group III. 
Occurrence of threats appeared to be highest in group III being 3.2\%, compared to $1.4 \%$ and $1.2 \%$ in groups I, II respectively.

Table III shows the effect of feeder space allowance on the growth performance of broilers. There was no significant effect of feeder space allowance on any of the growth performance parameters measured at $\mathrm{p}>0.05$.

\section{Discussion}

The significant effect of feeder space allowance on agonistic behaviour of birds during the feeding periods and the significant difference in agonistic behaviour during the feeding and "non feeding” period agreed with the findings of CUNNINGHAM (1981). He reported that agonistic acts were highest during ingestive activity. He found that birds with greater feeder space allowance initiated fewer numbers of aggressive head pecks per hour than those with smaller feeder space allowance. He suggested that this must have resulted from less competition during feeding when feeding space is sufficiently large.

During the feeding periods, steps and pushes were more common than threats and head pecks. This was attributed to competition for available feeder space. Usually, smaller and birds with weak legs were supplanted. Evidently, birds were more interested in feeding at those times than threatening other birds and this must have accounted for why threats were low. Threats during feeding were highest in group III, this is thought to be due to excessive feeder space allowance when the birds were younger. This point was driven home by the observation that the trend of higher threats in group III decreased as the birds grew older and consequently needed more space.

During "non-feeding" periods, there was no effect of feeder space allowance on agonistic acts. This was attributed to less tension among birds. At those periods, birds were generally not competing for feed, and most of them engaged in comfort behaviour (MAULDIN, 1992).

There was no significant effect of feeder space allowance used in this study on the growth performance parameters measured. This contrasted with the report by OUARTS and ADAMS (1982) that reported a significant difference in average body weight gain in the birds used in their study. This difference could be due to the fact that the birds used in this study were raised on floor, whereas the birds used in the study of OUART and ADAMS (1982) were raised in cages. More plausibly, the increment in feeder space allowance in OUARTS and ADAMS (1982) study was 10.2 $\mathrm{cm}$ in contrast to $0.6 \mathrm{~cm}$ used in this study.

From this study, it is concluded that $2.4 \mathrm{~cm} /$ bird feeder space allowance was sufficient for the broilers used. Although it led to more agonistic acts, it did not adversely affect the growth performance of the birds concerned.

\section{Acknowledgement}

The authors wish to acknowledge the support of Obafemi Awolowo University, Ile Ife in funding this as well as their research works.

\section{References}


CUNNIGHAM, D.L.:

The Effects of Social Rank and Cage Shape on Selected Behavioural and Performance Traits of White Leghorn Layers. Poultry Sci. 60 (1981), 2593-2598

DUNCAN, D.B.:

Multiple Range and Multiple F Tests. Biometrics. 11 (1955), 1-15

MAULDIN, J.M.:

Applications of Behaviour to Poultry Management. Poultry Sci. 71 (1992), 634-642

O’KEEFE, T.R.; GRAVES, A.B.; SIEGEL, H.S.:

Social Organization in Caged Layers: The Peck Order Revisited. Poultry Sci. 67 (1988), 1008-1014

OLUYEMI, J.; ROBERTS, F.A.:

Poultry Production in Warm Wet Climates. Macmillan Publishers Ltd., London and Basingstoke, pp. 82-91. 1988

OUART, M.D.; ADAMS, A.W.:

Effects of Cage Design and Bird Density on Lay 2. Bird Movement and Feeding Behaviour. Poultry Sci. 61 (1982), 1614-1620

SIEGEL, P.B.:

Behaviour-Genetic Analysis and Poultry. Poultry Sci. 72 (1993), 1-6

SNEDECOR, G.M.; COCHRAN, W.G.:

Statistical Methods. Iowa State University Press, Ames, Iowa, pp. 299-388. 1967

STONE, N.N.; SIEGEL, P.B.; ACKINSSON, C.S.; GROSS, W.N.B.:

Vocalization and Behaviour of Two Commercial Stocks of Chicken. Poultry Sci. 51 (1984), 1928-1937

Received: 2000-08-17

Accepted: 2002-03-01

Corresponding author

OLUYINKA A. OLUKOSI (B. Agric.)

Department of Animal Science

Faculty of Agriculture

Obafemi Awolowo University

Ile Ife

Nigeria

E-Mail: oolorunn@oauife.edu.ng 